\title{
Psychosemantic Features of Professional Consciousness of Engineers
}

\section{Психосемантичні особливості змісту професійної свідомості інженерів}

\author{
Olha Drobot \\ Dr. in Psychology, \\ Professor
}

\author{
Ольга Дробот \\ доктор психологічних наук, \\ професор
}

E-mail: piterkiev@gmail.com orcid.org/0000-0001-5999-7632

\author{
National Aviation University, \\ Department of Pedagogy and \\ Psychology of Vocational Education \\ 1, Kosmonavta Komarova Pr., \\ Kyiv, Ukraine, 03065
}

\author{
Національний авіаційний \\ університет, кафедра педагогіки \\ та психологї̈ професійної освіти \\ $\bowtie$ пр. Космонавта Комарова, 1, \\ м. Київ, Україна, 03065
}

Original manuscript received April 25, 2018

Revised manuscript accepted January 30, 2019

\begin{abstract}
This article presents results of an empiric study of psychosemantic features of professional consciousness of engineers: the associative structure of key professional notions has been determined, and its key properties have been revealed. The method of free associations has been applied; J. Sax's and S. Levis's Unfinished Sentences projective technique; original questionnaire. It was proved that engineers are distinguishable for the desire to get promoted to a higher position while retaining inclination toward the present area of activity; functional autonomy; dependence on organization; internal control locus in the situation of professional problems; longterm professional planning; orientation toward refraining from inflicting damages upon others and themselves; balanced moral principles. An associative experiment has been held with stimuli words that concern professional sphere and with words unrelated to the profession. 1524 reactions to 37 stimuli words have been received
\end{abstract}


in total. Building associative complexes for every stimulating notion allowed to reflect contemporary perceptions of respondents about each of them. The following most frequently occurring associations to the "work» stimulus have been highlighted: knowledge, experience, skills, work routine, Monday-Friday, boss, half-life, prospects, growth, success, hard. One of the features of professional consciousness of engineers is fixation of own subordination in performance of professional duties; inclination toward timely accomplishment of simple professional tasks; orientation of mindset toward integrity and discipline in business communication.

Key words: professional consciousness, engineers, psychosemantics, associative experiment.

\section{Вступ}

Актуальність дослідження випливає безпосередньо 3 практичних завдань економічного життя країни, вирішення яких у великій мірі забезпечується за рахунок ефективного виробництва. Ефективне виробництво сьогодні неможливе без глибокої уваги науки до психологічної природи свідомості інженера, іiі структури та закономірностей функціонування.

У вітчизняній $i$ пострадянській психологї в галузі психосемантики та психології суб'єктивної семантики досліджуються: професійна складова у структурі образу світу i динаміка професійної семантики (Дробот, 2014; Савеленко, 2000; Ханина, 2011); психосемантичні методи опису професії (Артемьева \& Вяткин, 1986); механізми діяльності свідомості (Аллахвердов, 2000; Агафонов, 2003; Лозова, 2011).

Сучасні дослідження професійної свідомості інженерів, опубліковані у зарубіжних наукових жсурналах, представлені переважно тематикою інженерного мислення (Davis, 1991) та етики (Whitbeck, 1998). Зокрема, в контексті дослідження етичних компетенцій інженерів, А. Malitowska доходить того висновку, що професійна свідомість інженера «піддається критичному діалогу i перегляду існуючих рішень, що в кінцевому підсумку призводить до розвитку спеціальних знань та підвищенню стандартів професійної практики» (Malitowska, 2017).

3 іншого боку, психологічне осмислення діяльності інженера стикається 3 недостатністю необхідних джерел та майданчиків для 
суспільного обговорення. Зокрема, P. Wajszczyk, аналізуючи етичні зобов'язання інженерів, вказує на виникнення таких проблеми при навчанні професійної інженерної етики, як відсутність необхідних навчальних матеріалів польською мовою та відсутність форуму для обговорення етичних проблем техніки в Польщі як у галузі навчання, так і в галузі досліджень (Wajszczyk, 2013). В Україні 3 науковим осмисленням інженерної свідомості, зокрема, іiї етичного компоненту, на сьогодні склалася аналогічна ситуація.

Проблема полягає в тому, що на фоні досліджень психологоетичних аспектів інженерної праці, інженерного мислення та компетенцій тотально відсутні дослідження змістової структури професійної свідомості інженерів.

В руслі психосемантичної парадигми ми визначаємо професійну свідомість інженера як вищий рівень психічного відображення світу професії, його рефлексію та саморегуляцію даного відображення. Цей різновид професійної свідомості існує в семантичному полі професійної культури певної території в конкретну історичну епоху. Структурно професійна свідомість інженера являє собою сукупність чуттєвих та уявних образів, які безпосередньо наповнюють досвід професійної діяльності інженера; ядром даної структури виступають значення і смисли, зміст яких диктується змістом предмета й цілями професійної діяльності, та чуттєвої тканини образу, яка виражається у професійній диференційованості сприйняття.

Мета дослідження полягає у виявленні психосемантичного змісту професійної свідомості інженерів.

Завдання дослідження: у змісті інженерної свідомості визначити асоціативну структуру концепту «робота» та семантику інших професійних лексем, які не входять в асоціативне поле «робота»; виявити провідні компоненти структури семантичного поля поняття «типовий інженер» у інженерів та порівняти їх зі структурою семантичного поля представників контрольної групи досліджуваних.

Аналіз попередніх досліджень. Науковий інтерес психологів до тематики, наближеної до проблеми професійної свідомості інженерів, хронологічно розпочинається 3 досліджень Е.С. Чугуновою соціально-психологічних установок інженерів. У $80-\mathrm{x}$ роках минулого століття автором було виявлено, що у професійних установках відбивається позиція суб'єкта стосовно діяльності, яка 
може бути позитивною, негативною або індиферентною (Чугунова, 1984, 1986). На увагу заслуговує п’ятикомпонентна структура установки, запропонована Е.С. Чугуновою у застосуванні до професійної свідомості інженерів. Основні рівні установки тут такі: сензитивний, когнітивний, комунікативний, оцінний i праксичний. Сензитивний елемент виражає або концентрує в собі емоційне ставлення особистості до професії; когнітивний відображає рівень пізнавальної активності особистості в плані ㄲi професійного розвитку; комунікативний елемент визначає поведінковий аспект, перспективність взаємозв'язків професіонала 3 організацією 3 погляду соціального мікроклімату й самовираження особистості; оцінний елемент виражає ступінь задоволеності особистості спеціальністю, взаєминами в мікрогрупі; праксичний елемент визначає психологічну готовність діяти в певному напрямку (Чугунова, 1984, 1986).

У подальшому цей напрям знайшов свої продовження в дослідженнях загальних правил, програм професійної поведінки інженерів та більш широкого поняття професійної культури (Калекина, 2009; Петрунева, 2001).

У західній науці інженерія розглядається як окрема форма культури, з притаманним їй набором правил і способів практики культура, відмінна від науки, рівно як і не прикладний аспект науки. Мета автора полягає в тому, щоб показати природу інженерних знань, як вони отримуються i 3 чого складаються. Основна теза полягає в тому, що інженери мають свої власні методи, процедури і сукупність навичок, в результаті чого вони створюють знання. Vincenti дотримується цілковито когнітивного погляду на те, як зросте й розвивається інженерне знання. Намагаючись відокремити інженерні знання від соціального контексту, практики i неформальних традицій, в які воно вбудоване, автор у результаті цього постулює модель типу варіації-вибору універсального змісту (Vincenti, 1990).

Теоретична психолінгвістика визначає рідну мову суб'єкта як детермінанту моделі навколишнього світу, як «сітку координат», за допомогою якої люди сприймають дійсність і будують образ світу, що існує в їхній свідомості» (Гуревич, 1972: 15-16). Пізніше цю думку розвиває В.В. Красних: модель світу уявляється дослідницею 
як система кодів культури, як «сітка», яку їі культура «накидає» на навколишній світ, членує, категоризує, структурує та оцінює його (Красных, 2002: 232). Коди культури співвідносяться з найдавнішими архетипними уявленнями людини. Як феномени, універсальні за своєю природою, вони властиві людині як homo sapiens. Однак їх виявлення, питома вага кожного 3 них у певній культурі, а також метафори, у яких вони реалізуються, завжди соціально детерміновані, i у нашому випадку, зумовлюються конкретно професійною культурою інженера. Образ професії міститься у свідомості суб’єкта в формі певної знакової системи. Найбільш специфічною для формування, збереження та трансляції образу $є$ знакова система мови, тому цілком припустимо розцінювати тексти, продуковані досліджуваним за доволі вільними інструкціями, як вербальний образ професії.

В галузі прикладної психолінгвістики дослідники торкаються професійних аспектів мовленнєвого мислення інженерів, зокрема, у сфері мовного спілкування і масової комунікації. Так, аналізуючи категоріальні ознаки мовлення, О.О. Леонтьєв розглядає їх в контексті виконуваних суб'єктом соціальних ролей i соціальних статусів. Соціальні ролі диктують різницю у вживанні мовних засобів: «Уявімо собі таку ситуацію. Якийсь чоловік (А) працює майстром на заводі. Природно, що його мова відрізняється від мови, припустимо, конструктора або робочого сцени в театрі. Але ось наш А покинув стіни заводу і відправився в шаховий клуб судити змагання. Він потрапляє в іншу систему відносин, змінюється його соціальна роль, змінюється коло спілкування (в змаганнях можуть брати участь і артист, і робочий, і вчитель), змінюється його мова» (Леонтьев, 2008: 24).

До соціальних статусів мовця вчений відносить і професію: «У поняття соціального статусу входить професія людини, рівень його культури і т. П.» При цьому, соціальний статус суб'єкта, відповідно до поглядів О.О. Леонтьєва, формує соціальні діалекти, різновидами яких учений вважає професійні мови і жаргони: «Якщо професійні мови часом характеризують широке коло спеціальностей (скажімо, інженери-конструктори, які працюють за будь-якою спеціальністю, вживають слова кульман, рейсшини і т. п.), то жаргони «видають» представника певної професії відразу» (там само: 25). 
Окремі проблеми мислення й мови інженерів розкрито в роботах I.M. Лущихіної, де розглядаються аспекти, пов'язані 3 оптимальною синтаксичної формою команд, що одержують i передають диспетчери аеропорту (Лущихина, 1968). Розглядається також професійна комунікація інженерів, яка реалізується в таких формах, як: ділова бесіда, ділові переговори, суперечка, дискусія, полеміка, ділову нараду, публічний виступ, телефонні розмови, ділове листування (Мамаева, 2018).

За даними «Російського асоціативного словника», матеріали до якого збиралися в 1988-1998 роках, словесна реакція «інженер» входила в асоціативне поле слова-стимулу «Я» (Русский ассоциативный словарь, 2002: 744). У «Слов'янському асоціативному тезаурусі» асоціат «інженер» входить в асоціативне поле стимулів «машина» та «робота»; україномовних реакцій встановлено не було (Славянский ассоциативный словарь, 2004).

На жаль, інтерес психолінгвістики до професійної групи інженерів нерідко обмежується проблематикою оволодіння іноземними мовами. Так, М.В. Мельников дослідив ефективність формування іншомовної компетентності майбутніх інженерів у процесі навчання англійської мови 3 використанням психолінгвістичних формул. За своєю суттю ця праця $\epsilon$ дослідженням мовленнєвої свідомості, оскільки вчений визначає провідну модальність студентів (аудіальна, візуальна, кінестетична) i докладає експериментальних зусиль до зміни стилю навчання відповідно до навчальної ситуації на основі діагностики провідної модальності студентів. Результативний блок моделі, що відображає ступінь сформованості мовленнєвої компетентності майбутніх інженерів, в якості основних компонентів включає в себе емоційноціннісний критерій; критерій засвоєння навчальних дій (когнітивну i діяльнісної-практичну складові) та комунікативний критерій (Мельников, 2011).

Як показав аналіз, вітчизняних класичних i сучасних досліджень, опублікованих у психолінгвістичних монографічних та дисертаційних виданнях, в яких би визначалися психологічні властивості та психосемантичний зміст професійної свідомості інженерів, не існує. Тому рівень дослідженості психосемантичного змісту і структури професійної свідомості суб'єкта інженерної 
Психосемантичні особливості змісту професійної свідомості...

діяльності у психологічній науці залишається абсолютно недостатнім.

\section{Методи та методики дослідження}

У дослідженні було використано такі методики.

Метод вільних асоціацій (модифікація В.А. Семиченко). Для проведення асоціативного експерименту дібрано 37 слів-стимулів, серед яких ті, що стосуються професійної сфери (робота, гроші, договір, страх, переговори, транспорт, інформація, підлеглий, багатство, колектив, допомога, комп'ютер, акт, договір, протокол, завдання, зустріч), і ті, що не стосуються професії (віра, сім'я, союз, влада, сад, дах, пиво, музика, квіти, друзі, бізнес, щастя, дитя, неділя, телевізор, сонце, пісня, батько, мати, погода). Всього було отримано 1524 реакції на 37 слів-стимулів. Побудова асоціативних комплексів для кожного зі стимульних понять дозволила відобразити актуальні уявлення респондентів про кожне з них.

Семантичний диференціал «Типовий інженер». Методика була укладена за результатом проведення двох попередніх процедур: асоціативного та пілотажного досліджень. В межах першої процедури в експертній групі інженерів $(\mathrm{n}=25)$ за допомогою методу спрямованого асоціативного експерименту (з вимогою реагування прикметниками) було виявлено асоціації, які найчастіше виникають у респондентів на стимул «типовий інженер». Найчастотніші асоціати було покладено в основу шкал вербального семантичного диференціала. При цьому було виконано вимогу пропорційної розмірності шкал класичного семантичного диференціала оцінки (вираження суб'єктивного ставлення досліджуваного до об'єкта оцінювання), сили (відображення притаманних об'єкту властивостей, які не залежать від суб'єктивних оцінок) та активності (потенційної дієвості об'єкта). В межах пілотажного експерименту переслідувалася мета доведення відповідності наскрізної семантики тестових шкал суті самого об'єкта оцінювання. Це завдання було вирішено за рахунок пілотажної процедури (Дробот, 2014).

Вибірка дослідження. Експериментальну групу склали 63 особи фахових інженерів, серед них 49 чоловіків (79\%) та 14 жінок (21\%). Вік досліджуваних - в діапазоні від 26 до 61 років, 
всі члени зазначеної професійної групи мали базову технічну освіту 3 різноманітних інженерних спеціальностей (інженерелектрик, механік, будівельник, програміст, акустик, технолог) та професійний досвід від 5 до 38 років. Контрольною групою стали 70 осіб з числа керівників середньої ланки виробничих підприємств. Контрольна група була рандомізована за тими ж критеріями, що й експериментальна. Дослідження проводилося в реальній професійній ситуації, на підприємствах України (Одеса, Київ, Миколаїв, Львів). В цілому, структура вибірки дає підстави вважати інформацію про зміст професійної свідомості інженерів адекватною реальності.

\section{Результати та дискусії}

Аналізувалися відповіді досліджуваних на питання тесту «Типовий інженер». В цілому, оцінки досліджуваних розмістилися в позитивній площині семантичного простору значень. Перевірялася гіпотеза про рівність середніх значень окремих шкал тесту між групами досліджуваних, для чого вираховувалися середні значення за кожним питанням, стандартна похибка, модуль різниці $D$, Z-статистика та $p$-значення. Для перевірки гіпотези про рівність середніх значень було використано критерій згоди КолмогороваСмирнова. Результати обчислень розміщено в таблиці 1.

Таблиця 1. Перевірка гіпотези про рівність середніх значень між групами керівників $(\mathrm{n}=70)$ та інженерів $(\mathrm{n}=63)$

\begin{tabular}{|c|c|c|c|c|c|c|c|}
\hline \multirow{2}{*}{$\begin{array}{c}\text { Статистики } \\
\text { Конструкти } \\
\text { семантичного } \\
\text { диференціала } \\
\text { «Типовий інженер» }\end{array}$} & \multicolumn{2}{|c|}{$\begin{array}{c}\text { Середнс } \\
\text { значення, М }\end{array}$} & \multicolumn{2}{|c|}{$\begin{array}{l}\text { Стандартна } \\
\text { похибка, m }\end{array}$} & \multicolumn{3}{|c|}{$\begin{array}{c}\text { Статистика } Z \mathbf{Z} \\
\text { Колмогорова-Смирнова }\end{array}$} \\
\hline & 递 & 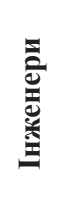 & 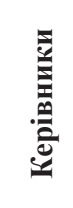 & 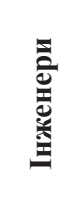 & 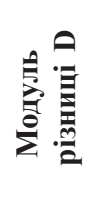 & 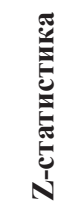 & 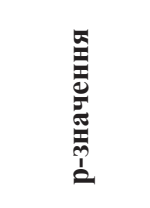 \\
\hline Практичний & 2,2 & 5,7 & 0,26 & 0,09 & 0,434 & 2,497 & $<0,001 * * *$ \\
\hline Зрілий & 5,1 & 6,7 & 0,19 & 0,04 & 0,199 & 1,147 & 0,144 \\
\hline Мудрий & 6,2 & 6,4 & 0,12 & 0,12 & 0,022 & 0,129 & 1,000 \\
\hline Непитущий & 3,3 & 5,4 & 0,22 & 0,19 & 0,259 & 1,492 & $0,023^{*}$ \\
\hline Принциповий & 4,9 & 5,6 & 0,05 & 0,07 & 0,099 & 0,568 & 0,903 \\
\hline Розумний & 4,5 & 3,9 & 0,03 & 0,18 & 0,072 & 0,417 & 0,995 \\
\hline
\end{tabular}


Психосемантичні особливості змісту професійної свідомості...

\begin{tabular}{|c|c|c|c|c|c|c|c|}
\hline Працелюбний & 6,5 & 3,0 & 0,35 & 0,25 & 0,442 & 2,543 & $<0,001 * * *$ \\
\hline Комунікабельний & 6,0 & 3,4 & 0,09 & 0,17 & 0,329 & 1,897 & $0,001 * * *$ \\
\hline Ентузіаст & 3,6 & 3,0 & 0,27 & 0,12 & 0,077 & 0,442 & 0,990 \\
\hline Загартований & 6,0 & 6,9 & 0,34 & 0,03 & 0,105 & 0,607 & 0,854 \\
\hline Дотепний & 6,3 & 3,2 & 0,28 & 0,02 & 0,380 & 2,187 & $<0,001 * * *$ \\
\hline Діловий & 5,9 & 6,7 & 0,07 & 0,09 & 0,101 & 0,579 & 0,891 \\
\hline Простий & 6,0 & 3,7 & 0,08 & 0,20 & 0,291 & 1,678 & $0,007 * *$ \\
\hline Доброзичливий & 5,6 & 6,9 & 0,05 & 0,08 & 0,170 & 0,977 & 0,295 \\
\hline Щасливий & 5,3 & 6,8 & 0,34 & 0,22 & 0,195 & 1,123 & 0,160 \\
\hline Мужній & 5,9 & 6,6 & 0,02 & 0,22 & 0,092 & 0,528 & 0,943 \\
\hline Самовдоволений & 4,9 & 6,4 & 0,04 & 0,15 & 0,188 & 1,081 & 0,193 \\
\hline Організований & 5,7 & 5,9 & 0,10 & 0,06 & 0,026 & 0,150 & 1,000 \\
\hline Розкутий & 5,2 & 6,2 & 0,10 & 0,14 & 0,135 & 0,775 & 0,586 \\
\hline Спортивний & 5,8 & 4,1 & 0,11 & 0,18 & 0,207 & 1,193 & 0,116 \\
\hline Перспективний & 6,1 & 3,7 & 0,35 & 0,05 & 0,307 & 1,765 & $0,004 * *$ \\
\hline Новатор & 6,8 & 6,5 & 0,27 & 0,19 & 0,033 & 0,192 & 1,000 \\
\hline Скромний & 6,0 & 6,1 & 0,29 & 0,07 & 0,009 & 0,053 & 1,000 \\
\hline Веселий & 6,3 & 2,7 & 0,07 & 0,20 & 0,455 & 2,620 & $<0,001 * * *$ \\
\hline Активний & 7,0 & 6,6 & 0,29 & 0,20 & 0,042 & 0,243 & 1,000 \\
\hline Привабливий & 6,1 & 3,4 & 0,06 & 0,03 & 0,331 & 1,906 & $0,001 * * *$ \\
\hline Моральний & 6,7 & 4,7 & 0,20 & 0,06 & 0,255 & 1,470 & $0,026^{*}$ \\
\hline Елегантний & 6,3 & 6,6 & 0,19 & 0,06 & 0,046 & 0,266 & 1,000 \\
\hline Раціональний & 6,9 & 5,5 & 0,13 & 0,13 & 0,175 & 1,006 & 0,263 \\
\hline Елітарний & 6,1 & 4,1 & 0,05 & 0,20 & 0,260 & 1,500 & $0,022 *$ \\
\hline
\end{tabular}

Позначкою * в таблиці позначені $\mathrm{p}<0.05,{ }^{* *} \mathrm{p}<0.01,{ }^{* * *} \mathrm{p}<0.001$.

Психосемантичний «портрет» типового інженера у свідомості управлінців складається з рис людини активної, раціональної, притягальної, проте обережної, працьовитої, оптимістичної, успішної, простої, інноваційної.

Психосемантичний «портрет» типового інженера у свідомості самих інженерів складається 3 рис доброзичливості, загартованості, щасливості, діловитості, зрілості, мужності, елегантності, активності, новаторства, самовдоволеності, мудрості, розкутості, скромності. Таким чином, гіпотезу про рівність середніх значень суб'єктивного оцінювання якостей типового інженера між групами керівників та інженерів відхилено. 
3 метою визначення асоціативної структури концепту «робота» у групі інженерів була проведена дослідницька процедура вільного асоціативного експерименту 3 фіксацією найчастотніших асоціації. Нижче представлено результати асоціювання тих стимулів, які пов'язані зі сферою праці.

На стимул «робота» було отримано такі реакції: знання, досвід, уміння, трудові будні, понеділок-п'ятниця, шеф, півжиття, перспектива, зростання, успішність, важка. Пропорційно ці реакції в асоціативному мікрополі поняття «робота» займають позиції, представлені на рис. 1.
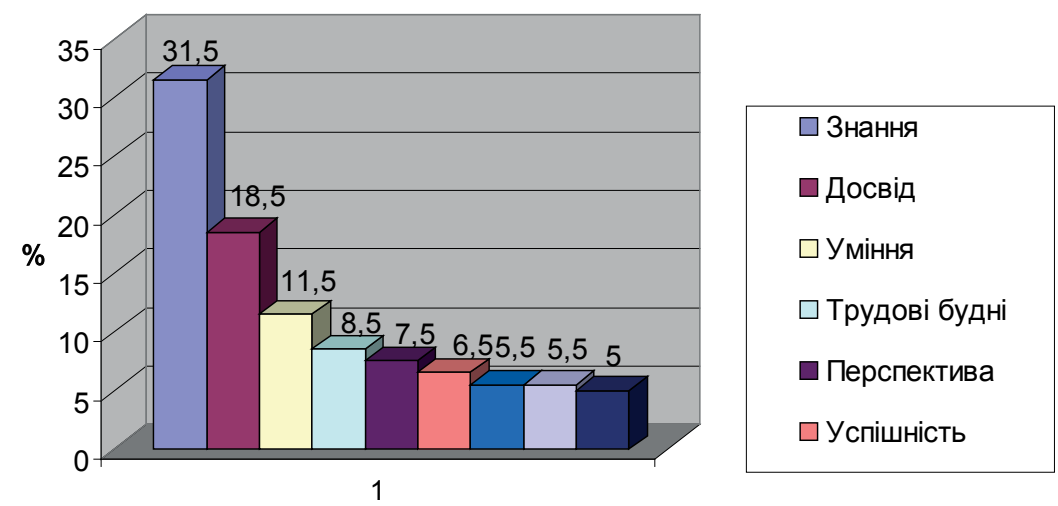

Асоціати

Рис. 1. Асоціативне мікрополе концеепту «робота» (група інженерів, $n=63$ )

Отже, семантика концепту «робота» у фахівців інженерних спеціальностей тісно пов'язана 3 групою понять, які можна узагальнити категорією «компетенції» (знання, уміння, досвід); своїй нелегкій роботі такий фахівець віддає значну частину свого часу (півжиття); в роботі інженера існує досить рутинних моментів (трудові будні з понеділка до n'ятнииі); попри це праця для інженерів передбачає перспективу й успішність. Важливим атрибутивним елементом роботи інженерів є особа керівника (щеф).

Цікавою також $є$ семантика професійних лексем, які входять в асоціативні мікрополя інших концептів, поза концептом «робота». Проаналізований масив цих асоціатів наведено нижче.

Гроші - самодостатність, незалежність, влада, свобода, скажені, куди їх витратити, зарплата, щастя, зло, необхідність, товар. Віра - казка, наївність, омана, жіноче ім'я, церква, невіра, 
релігія, духовність, відкритість, мораль, оптимізм. Сім'я - затишок, любов, вірність, турбота, діти, дорога, дружня, я вдома, син, чоловік, рідні, клан, діти, щастя. Договір - зобов'язання, документ, постачальник, покупець, наказ, чесний, гроші, контракт, документ, згода. Страх - слабкість, боягузтво, невпевненість, майбутнє, крижаний, нестійкість, хвороба, переляк, небезпека, скутість. Переговори - чесність, вміння, переговорний пункт, телеграф, краватка, круглий стіл, спілкування, успішні, компроміс, рішення, обговорення, компроміс, ретельність. Транспорт - пересування, поїздка, переліт, маршрутка, громадський, вібростенд, маршрутка, шум, незручність, шум, швидкість. Пиво - шкода, підробка, футбол, анчоуси, літо (спека), піна, риба, головний біль, тепле, футбол, напій, алкоголь. Музика - насолода, відпочинок, розслаблення, медитація, гучна, мелодія, танці, інструментальна, попса, гарний настрій, переживання, релакс. Квіти - запахи, кольорова палітра, бджола, ботанічний сад, 8 березня, троянда, піони, гвоздики, краса, подарунок, сюрприз. Друзі - надійність, захист, підтримка, мало, з дитинства, Тарас, день народження, гітара, пісні, одноклассники.ру, вірність, доброта, досвід. Бізнес - гроші, переговори, підступ, справа, угода, машина, торгівля, банкрутство, небезпечно, справа, зайнятість, дохід, партнери. Щастя - гармонія, ейфорія, безтурботність, сім'я, скороминуче, радість, внутрішній спокій, гроші, сім'я, діти, любов. Дитина - тепло, щастя, дзвінкий голос, син, інтерес, вундеркінд, переживання, сім'я, майбутнє, спадкоємець. Неділя - вихідний, відпочинок, подорож, відпочинок, прощена, дача, будинок, прогулянка, відсипаюсь, уїкенд, домашні справи, відпочинок, подорож. Телевізор - погані новини, настирлива реклама, хороші ретро-сюжети, Інтернет (ютуб), ящик, новини, футбол, реклама, техніка. Інформація - влада, контроль, навіювання, брехлива, їжа, Інтернет, байти, корисна, доступна. Влада - гроші, жадібність, жадібна, чиновник, президент, помаранчеві, блакитні, Янукович, корупція, нажива, насильство. Сад - відпочинок, бджоли, квіти, фрукти, город, квітучий, вишня, дерева, фруктовий, цвітіння, ягоди. Підлеглий - працівник, праця, завдання, дурень, ледачий, молодий, килим, хороша людина. Сонще - тепло, літо, пляж, море, місяць, тепле, спека, смажить, ультрафіолет, окуляри, яскраве, тепле, веселе. Багатство - гроші, жадібність, влада, недосяжно, зникле, досвід, рахунок у банку, будинок з високим парканом, яхта 
Абрамовича «Екліпс», фабрики, заводи, пароплави. Колектив команда, злагодженість, мета, тимчасово, спаяний, відпочинок на природі, корпоратив, бабський колектив, дружба, підтримка, досвід. Допомога - турбота, доброта, безкорисливість, сусіди, швидка, медицина, вчасно, у всьому. Комп'ютер - техніка, інформація, робота, Інтернет, зависає, залізо, фотошоп, торренти, Ексель, прогрес, інформація, архів, віруси. Акт - документ, друк, перелік, дія, приймання, папір, документ, дві печатки, заключний документ. Угода - згода, умови, компроміс, дотримуватися, шлюбний, було, дві сторони, зобов'язання, ділове, виконання. Пісня - музика, мелодія, вірші, голос, музика, народна, шумів очерет, гітара, гарний настрій, музика, веселощі, смуток. Батько - мужність, здобувач, повага, наставник, дорогий, дай грошей, дитинство, Далекий Схід, строгість, знання, досвід. Мати - турбота, любов, повага, берегиня, любов, мила, дай сорочку, Севастополь, телефон, поїздка, годування, доброта, турбота. Погода - настрій, сонце, вітер, настрій, дощова, спека, Інтернет, дощ, мінлива, сонячна, приємна. Протокол - документи, запис, нарада, обмін, підписаний, папір, підписи, ДАІ, збори, документ. Завдання - мета, справа, доручення, відповідальність, просте, термін, начальник, бойове завдання, конкретне, технічне. Зустріч - друзі, сім'я, радість, однокласники, тепла, де i коли, кафе, побачення, несподівана. Союз співдружність, договір, справа, Одеса, непорушний, непорушний, радянський, космічний корабель, СРСР, людей, держав. Дах - захист, затишок, стіна, будинок, будинок з трубою, протік, прокурорська (прокуратура), від дощу, від снігу, від сонця.

За результатами частотного аналізу була складена діаграма (рис. 2).

Серед великого масиву отриманих реакцій на інші стимули також мали місце асоціати, пов'язані зі світом професії. Серед останніх виділяється тема власної підлеглості у виконанні професійних обов'язків (підлеглий, працівник, технічне завдання, виконання); атрибутивні елементи доповнено понятяям «ділова угода» і «комп’ютер». Реакції на стимул «завдання» (мета, доручення, відповідальність, термін, просте, конкретне) свідчать про схильність фахівців до вчасного виконання нескладних професійних завдань. Інженери мають досить абстрактне уявлення про багатство, яке в 
них не пов'язане з роботою; розвинені інструментальні асоціати стосовно комп'ютера та установку на чесність і дисциплінованість у діловій комунікації (асоціати до стимулів «угода» і «переговори»).

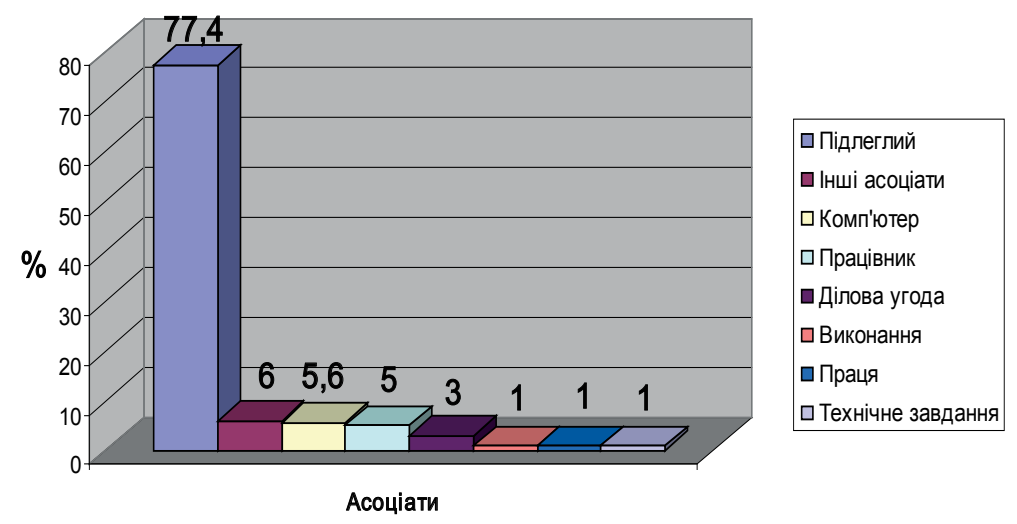

Рис. 2. Професійна семантика в асоиіативних мікрополях інших концептів $(n=63)$

\section{Висновки}

1. У статті вперше запропоновано визначення професійної свідомості інженера як вищого рівня психічного відображення світу професії, а також механізму рефлексії та регуляції даного відображення.

2. Науково інноваційним $є$ дослідження професійної свідомості інженерів в рамках психосемантики із застосуванням психосемантичних та психолінгвістичних методів дослідження.

3. Вперше емпірично встановлено асоціативну структуру свідомості професійної групи інженернерів. Зокрема, семантичне поле концепту «робота» тісно пов'язана 3 категорією компетенції, важкості, значних витрат часу, рутинності, передбачуваної перспективності та успішності. Важливим атрибутивним елементом роботи інженерів є особа керівника.

4. Визначено особливості професійної свідомості інженерів у тих асоціативних мікрополях стимулів, які не пов'язані безпосередньо 3 роботою. В цьому ареалі також зафіксована професійна семантика, доля якої складає 22,6\%. Спостерігається тематики власної підлеглості у виконанні професійних обов'язків; 
схильність до своєчасного виконання нескладних професійних завдань; розвинені інструментальні компетенції; настанова на чесність і дисциплінованість у діловій комунікації.

5. Констатовано, що психосемантика професійної сфери фахівців інженерних спеціальностей $\epsilon$ перспективною для психолінгвістичних досліджень в частині семантики концептів: «компетенції», «часові витрати», «рутинність», «перспектива» та «успішність».

\section{Література}

Агафонов А.Ю. Основы смысловой теории сознания: монографія. СанктПетербург : Речь, 2003. 296 с.

Артемьева Е.Ю., Вяткин Ю.Г. Психосемантические методы описания профессии. Вопросы психологии. 1986. № 3. С. 127-133.

Аллахвердов В.М. Сознание как парадокс (экспериментальная психологика) : монографія. Санкт-Петербург : ДНК, 2000. 528 с.

Гуревич А.Я. Категории средневековой культуры. Москва : Искусство, 1972. 318 c.

Дробот О.В. Психосемантика управлінської свідомості керівника. Одеса; Донецьк : Східний видавничий дім, 2014. 372 с.

Калекина А.В. Влияние профессиональной культуры на удовлетворенность трудом инженеров-конструкторов промышленных предприятий : автореф. дисс. ... канд. психол. наук : 19.00.07. Москва, 2009. 27 с.

Красных В.В. Этнопсихолингвистика и лингвокультурология. Москва : Гнозис, 2002. 284 c.

Леонтьев А.А. Прикладная психолингвистика речевого общения и массовой коммуникации. Москва : Смысл, 2008. 272 с.

Лозова О.М. Методологія психосемантичних досліджень етносу. Київ : Слово, 2011. $176 \mathrm{c}$.

Лущихина И.М. Экспериментальное исследование психолингвистической значимости грамматической структуры высказывания. Москва : Наука, 1968.

Мамаева А.В. Психолингвистические аспекты профессионального самоопределения инженера. Проблемы современного педагогического образования. 2018. 58(4). С. 160-163.

Мельников М.В. Формирование речевой компетентности будущих инженеров в процессе обучения английскому языку с использованием психолингвистических формул : на примере технического вуза : дисс ... канд. пед. наук. Ульяновск, 2011. 329 с.

Петрунева Р.М. Гуманитаризация инженерного образования (на основе моделирования социогуманитарной экспертизы технических решений) : дисс. ... д-ра пед. наук : 13.00.08. Волгоград, 2001. 336 с.

Русский ассоциативный словарь : В 2 т. / Ю.Н. Караулов, Г.А. Черкасова, Н.В. Уфимцева, Ю.А. Сорокин, Е.Ф. Тарасов. Т. І. От стимула к реакции : Ок. 7000 стимулов. Москва : АСТ-Астрель, 2002. 784 с. 
Савеленко В.М. Динамика профессионального сознания курсантов высших военных авиационных инженерных учебных заведений : дисс. ... канд. психол. наук : 19.00.07. Ставрополь, 2000. 148 с.

Славянский ассоциативный словарь : русский, белорусский, болгарский, украинский / Н.В. Уфимцева, Г.А. Черкасова, Ю.Н. Караулов, Е.Ф. Тарасов. Москва, 2004. 792 с.

Ханина И.Б. Динамика профессиональной семантики как показатель формирования профессионального мира. Психология субъективной семантики : Истоки и развитие. Москва : Смысл, 2011. С. 354-379.

Чугунова Э.С. Социально-психологические установки инженеров и их влияние на профессиональную деятельность. Научная организация труда и управления в научно-исследовательских и проектных учреждениях. Москва : Знание, 1984. C. $40-51$.

Чугунова Э.С. Социально-психологические особенности творческой активности инженеров : монография. Ленинград : ЛГУ, 1986. 160 с.

Davis, M. (1991). Thinking Like an Engineer : The Place of a Code of Ethics in the Practice of a Profession. Philosophy and Public Affairs, 20(2), 150-167.

Malitowska, A. (2017). Jakich kompetencji etycznych potrzebuje inżynier? Stowarzyszenie Inżynierów $i$ Techników Mechaników Polskich. Uniwersytet im. A. Mickiewicza w Poznaniu. URL: http://www.simp-poznan.pl/etyka.html

Wajszczyk, P. (2013). Etyka zawodu inżyniera w świetle wybranych kodeksów. Annales. Etyka w życiu gospodarczym, 16. Łódz : Wydawnictwo Uniwersytetu Łódzkiego. URL: http://www.annalesonline.uni.lodz.pl/archiwum/2013/2013 wajszczyk_241_258.pdf

Whitbeck, C. (1998). Ethics in Engineering Practice and Research. Cambridge : Cambridge University Press. https://doi.org/10.1017/CBO9780511806193

Vincenti, W.G. (1990). What Engineers Know and How They Know It. Analytical Studies from Aeronautical History. Baltimore : Johns Hopkins University Press.

\section{References}

Ahafonov, A.Yu. (2003). Osnovy smyslovoj teoryy soznanyia [Bases of semantic theory of consciousness]. Saint Petersburg: Rech [in Russian].

Artemeva, E.Yu., \& Viatkyn, Yu.H. (1986). Psykhosemantycheskye metody opysanyia professyy [Psychosemantic methods of describing the profession]. Voprosy psykholohyy - Questions of psychology, 3, 127-133 [in Russian].

Allakhverdov, V.M. (2000). Soznanye kak paradoks (eksperymentalnaia psykholohyka [Consciousness as a paradox (experimental psychology]. Saint Petersburg: DNK [in Russian].

Gurevich, A.Ya. (1972). Kategorii srednevekovoj kultury [Categories of medieval culture]. Moscow: Iskusstvo [in Russian].

Drobot, O.V. (2014). Psykhosemantyka upravlinskoi svidomosti kerivnyka [Psychosemantic of managerial consciousness of the head]. Odesa; Donetsk: Skhidnyi vydavnychyi dim [in Ukrainian].

Kalekyna, A.V. (2009). Vlyianye professyonalnoj kultury na udovletvorennost trudom ynzhenerov-konstruktorov promyshlennykh predpryiatyj [The influence of professional culture on the satisfaction of the labor of design engineers of industrial enterprises]. Extended abstract of candidate's thesis. Moscow [in Russian]. 
Karaulov, Ju.N., Cherkasova, G.A., Ufimceva, N.V., Sorokin, Ju.A., \& Tarasov, E.F. (2002). Russkij associativnyj slovar [Russian associative dictionary]. (Vols. 1-2). Moscow : AST Astrel [in Russian].

Krasnyh, V.V. (2002). Etnopsiholingvistika i lingvokulturologiya [Ethnopsycholinguistics and cultural linguistics]. Moscow: Gnozis [in Russian].

Leontev, A.A. (2008). Prikladnaya psiholingvistika rechevogo obshcheniya i massovoj kommunikacii [Applied psycholinguistics of verbal communication and mass communication]. Moscow: Smysl [in Russian].

Lozova, O.M. (2011). Metodolohiia psykhosemantychnykh doslidzhen etnosu [Methodology of psychosemantic ethnos research]. Kyiv: Slovo [in Ukrainian].

Lushchihina, I.M. (1968). Eksperimentalnoe issledovanie psiholingvisticheskoj znachimosti grammaticheskoj struktury vyskazyvaniya [An experimental study of the psycholinguistic significance of the grammatical structure of the utterance]. Moscow: Nauka [in Russian].

Mamaeva, A.V. (2018). Psiholingvisticheskie aspekty professionalnogo samoopredeleniya inzhenera [Psycholinguistic aspects of professional selfdetermination of an engineer]. Problemy sovremennogo pedagogicheskogo obrazovaniya - Problems of modern teacher education, 58(4), 160-163 [in Russian].

Melnikov, M.V. (2011). Formirovanie rechevoj kompetentnosti budushchih inzhenerov $\mathrm{v}$ processe obucheniya anglijskomu yazyku $\mathrm{s}$ ispolzovaniem psiholingvisticheskih formul : na primere tekhnicheskogo vuza [Formation of speech competence of future engineers in the process of teaching English using psycholinguistic formulas : on the example of a technical university]. Candidate's thesis. Ulyanovsk [in Russian].

Petruneva, R.M. (2001). Humanytaryzatsyia ynzhenernoho obrazovanyia (na osnove modelyrovanyia sotsyohumanytarnoj ekspertyzy tekhnycheskykh reshenyj) [Humanitarization of engineering education (based on modeling of social and humanitarian expertise of technical solutions)]. Doctor's thesis. Volhohrad [in Russian].

Savelenko, V.M. (2000). Dynamyka professyonalnoho soznanyia kursantov vysshykh voennykh avyatsyonnykh ynzhenernykh uchebnykh zavedenyj [Dynamics of professional consciousness of cadets of higher military aviation engineering educational institutions]. Candidate's thesis. Stavropol [in Russian].

Khanyna, Y.B. (2011). Dynamyka professyonalnoj semantyky kak pokazatel formyrovanyia professyonalnoho myra [Dynamics of professional consciousness of cadets of higher military aviation engineering schools]. Psykholohyia subektyvnoj semantyky: Ystoky y razvytye - Psychology of subjective semantics: premise and development, (pp. 354-379). Moscow: Smysl [in Russian].

Chuhunova, E.S. (1984). Sotsyalno-psykholohycheskye ustanovky ynzhenerov y ykh vlyianye na professyonalnuiu deiatelnost [Socio-psychological attitudes of engineers and their influence on professional activities]. Nauchnaia orhanyzatsyia truda y upravlenyia $v$ nauchno-yssledovatelskykh y proektnykh uchrezhdenyiakh Scientific organization of labor and management in research and design institutions, (pp. 40-51). Moscow: Znanye [in Russian].

Chuhunova, E.S. (1986). Sotsyalno-psykholohycheskye osobennosty tvorcheskoj aktyvnosty ynzhenerov [Socio-psychological features of the creative activity of engineers]. Lenynhrad: LHU [in Russian]. 
Ufimceva, N.V., Cherkasova, G.A., Karaulov, Ju.N., \& Tarasov, E.F. (2004). Slavjanskij associativnyj slovar : russkij, belorusskij, bolgarskij, ukrainskij [Slavic Associative dictionary : Russian, Belarusian, Bulgarian, Ukrainian]. Moscow [in Russian].

Davis, M. (1991). Thinking Like an Engineer : The Place of a Code of Ethics in the Practice of a Profession. Philosophy and Public Affairs, 20(2), 150-167.

Malitowska, A. (2017). Jakich kompetencji etycznych potrzebuje inżynier? Stowarzyszenie Inżynierów i Techników Mechaników Polskich. Uniwersytet im. A. Mickiewicza w Poznaniu. URL: http://www.simp-poznan.pl/etyka.html

Wajszczyk, P. (2013). Etyka zawodu inżyniera w świetle wybranych kodeksów. Annales. Etyka w życiu gospodarczym, 16. Łódz : Wydawnictwo Uniwersytetu Łódzkiego. URL: http://www.annalesonline.uni.lodz.pl/archiwum/2013/2013_ wajszczyk 241_258.pdf

Whitbeck, C. (1998). Ethics in Engineering Practice and Research. Cambridge : Cambridge University Press. https://doi.org/10.1017/CBO9780511806193

Vincenti, W.G. (1990). What Engineers Know and How They Know It. Analytical Studies from Aeronautical History. Baltimore : Johns Hopkins University Press.

\begin{abstract}
АНОТАЦІЯ
У статті викладено результати емпіричного дослідження психосемантичного змісту професійної свідомості інженерів: визначено асочіативну структуру основних професійних понять; виявлено ії основні властивості. Застосовано методи: вільних асоціацій; проективна методика «Незакінчені речення» Дж. Сакса та С. Леві; авторська анкета. Констатовано, що інженери вирізняються стремлінням зайняти більш високу посаду при збереженій прихильность до нинішньої сфрери діяльності; функціональною автономністю; залежністю від організації; внутрішнім локусом контролю в ситуації професійних негараздів; довготривалістю професійного планування; настанову на утримання від заподіяння шкоди іншим та собі; збалансованість моральних принципів. Проведено вільний асоціативний експеримент зі словамистимулами, що стосуються професійної сорери, а також з тими, що не стосуються професії.. Всього було отримано 1524 реакції на 37 слів-стимулів. Побудова асоціативних комплексів для кожного зі стимульних понять дозволила відобразити актуальні уявлення респондентів про кожне з них. Було виділено наступні найчастотніші асоціації на стимул "робота»: знання, досвід, уміння, трудові будні, понеділок-п'ятниия, шеф, півжиття, перспектива, зростання, успішність, важка. Особливістю професійної свідомості інженерів $\epsilon$ фіксачія власної підлеглості у виконанні професійних обов'язків); схильність до вчасного виконання нескладних професійних завдань; установка на чесність $і$ дисциплінованість у діловій комунікації.
\end{abstract}

Ключові слова: професійна свідомість, інженери, психосемантика, асоціативний експеримент. 
Psychosemantic Features of Professional Consciousness...

Дробот Ольга. Психосемантические особенности содержания профессионального сознания инженеров

\section{АННОТАЦИЯ}

В статье изложены результаты эмпирического исследования психосемантического содержания профессионального сознания инженеров: определена ассоциативная структура основных профессиональных понятий; выявлены её основные свойства. Применен метод свободных ассоциаций; проективная методика "Незаконченные предложения» Дж. Сакса и С. Леви; авторская анкета. Констатировано, что инженеры отличаются стремлением занять более высокую должность при сохраненной приверженности к нынешней сфрере деятельности; функциональной автономностью; зависимостью от организации; внутренним локусом контроля в ситуации профессиональных проблем; долгосрочностью профессионального планирования; установкой на воздержание от причинения вреда другим и себе; сбалансированностью моральных принципов. Был проведен ассоциативный эксперимент со словамистимулами, касающимися и не касающимися профессиональной сферы. Всего было получено 1524 реакции на 37 слов-стимулов. Построение ассоциативных комплексов для каждого из стимульных понятий позволила отобразить актуальные представления респондентов о каждом из них. Были выделены следующие наиболее частотные ассоциации на стимул "работа»: знания, опыт, умения, трудовые будни, понедельник-пятница, шеф, полжизни, перспектива, рост, успешность, тяжелая. Особенностью профессионального сознания инженеров является констатация собственной подчиненности в исполнении профессиональных обязанностей; склонность к своевременному выполнению несложных профессиональных задач; установка на честность и дисциплинированность в деловой коммуникации.

Ключевые слова: профессиональное сознание, инженеры, психосемантика, ассоциативный эксперимент. 